\title{
Extraction, purification, and activity of protease from the
}

\section{leaves of Moringa oleifera [version 1; peer review: 2 approved,}

\section{1 approved with reservations]}

\author{
Swarnali Banik1, Shrutidhara Biswas (iD)2, Srabani Karmakar(iD)1 \\ ${ }^{1}$ Department of Biotechnology, Techno India University, Kolkata, West Bengal, 700064, India \\ ${ }^{2}$ Department of Biotechnology, Indian Institute of Technology, Guwahati, Assam, 781039, India
}

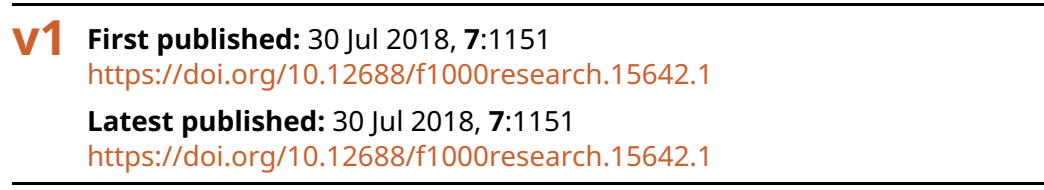

\section{Abstract}

Background: Proteases cleave proteins, thereby providing essential amino acids for protein synthesis, and degrade misfolded and damaged proteins to maintain homeostasis. Proteases also serve as signaling molecules, therapeutic agents and find wide applications in biotechnology and pharmaceutical industry. Plant-derived proteases are suitable for many biomedical applications due to their easy availability and activity over a wide range of $\mathrm{pH}$, temperature, and substrates. Moringa oleifera Lam (Moringaceae) is a very common food plant with medicinal property and geographically distributed in tropical countries. Here, we isolate proteases from the leaves of Moringa oleifera and characterize its enzymatic activity.

Methods: Proteases were isolated from the aqueous leaf extract of Moringa oleifera by ammonium sulfate precipitation and purified by ion exchange chromatography. Subsequently, the enzyme kinetics was determined using casein as a substrate and calibrated over different $\mathrm{pH}$ and temperature range for maximal activity.

Results: We obtained purified fraction of the protease having a molecular weight of $51 \mathrm{kDa}$. We observed that for the maximal caseinolytic activity of the protease, a pH of 8 and temperature of $37^{\circ} \mathrm{C}$ was found to be most effective.

Conclusion: The plant-derived proteolytic enzymes are finding increasing clinical and industrial applications. We could extract, purify and characterize the enzymatic activity of proteases from the leaves of Moringa oleifera. Further molecular characterization, substrate specificity and activity of the extracted protease are required for determining its suitability as a proteolytic enzyme for various applications.

\section{Keywords}

Casein, Enzyme activity, Leaf extract, Moringa Oleifera, Plant-derived proteases, Protein purification.

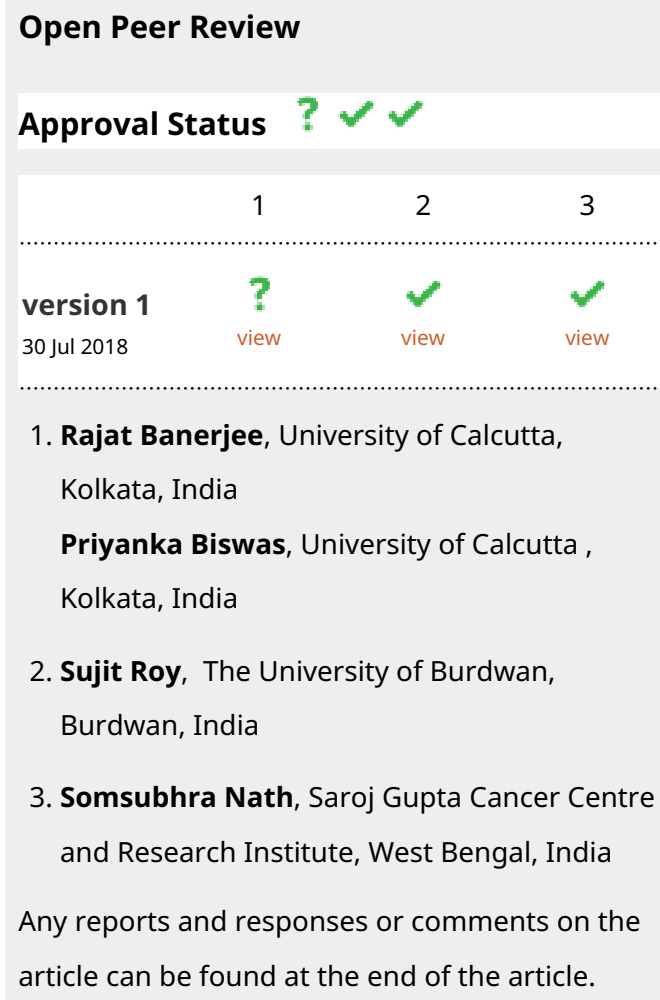

(3)

1. Rajat Banerjee, University of Calcutta,

Kolkata, India

Priyanka Biswas, University of Calcutta ,

Kolkata, India

2. Sujit Roy, The University of Burdwan,

Burdwan, India

3. Somsubhra Nath, Saroj Gupta Cancer Centre and Research Institute, West Bengal, India

Any reports and responses or comments on the article can be found at the end of the article. 
Corresponding author: Srabani Karmakar (snat14@gmail.com)

Author roles: Banik S: Formal Analysis, Investigation, Validation, Writing - Original Draft Preparation; Biswas S: Formal Analysis, Investigation, Validation, Writing - Original Draft Preparation; Karmakar S: Conceptualization, Methodology, Project Administration, Resources, Supervision, Writing - Review \& Editing

Competing interests: No competing interests were disclosed.

Grant information: The author(s) declared that no grants were involved in supporting this work.

Copyright: @ 2018 Banik S et al. This is an open access article distributed under the terms of the Creative Commons Attribution License, which permits unrestricted use, distribution, and reproduction in any medium, provided the original work is properly cited. Data associated with the article are available under the terms of the Creative Commons Zero "No rights reserved" data waiver (CC0 1.0 Public domain dedication).

How to cite this article: Banik S, Biswas S and Karmakar S. Extraction, purification, and activity of protease from the leaves of Moringa oleifera [version 1; peer review: 2 approved, 1 approved with reservations] F1000Research 2018, 7:1151

https://doi.org/10.12688/f1000research.15642.1

First published: 30 Jul 2018, 7:1151 https://doi.org/10.12688/f1000research.15642.1 


\section{Introduction}

All organisms contain proteases that hydrolyze peptide bonds in order to maintain systemic homeostasis and for its normal growth and development ${ }^{1,2}$. Proteases derived from plants, animals and microbes find wide industrial applications including in the leather, food, brewery and pharmaceutical industry ${ }^{2-4}$ corresponding to approximately $60 \%$ of the total worldwide enzyme sales ${ }^{5}$.

Moringa oleifera is one of the best known medicinal plants widely distributed in the tropical regions ${ }^{6}$. It contains a mixture of several hydrolytic enzymes, in which proteases are the key enzymes reported to show pharmacological activity ${ }^{7}$. We attempted to investigate the protease activity of aqueous extracts of Moringa oleifera leaf. Here, we have isolated and purified the protease from Moringa leaves and carried out enzyme kinetics study and find that the protease exhibited optimal caseinolytic activity in alkaline $\mathrm{pH}$.

\section{Methods}

\section{Preparation of crude enzyme extract}

Mature Moringa Oleifera leaves were collected from a plant located near TIU campus, Salt Lake Kolkata and crushed along with $20 \mathrm{mM}$ phosphate buffer $(\mathrm{pH} 7.5)$ and $0.1 \%$ tween 20 detergent and protease cocktail inhibitor followed by centrifugation with plastocraft table top refrigerated centrifuge machine (Rota $4 \mathrm{RV} / \mathrm{FM}$ ) at $10000 \mathrm{rpm}$ for $10 \mathrm{mins}$ at $4^{\circ} \mathrm{C}$. The crude soup was mixed with $40 \%$ ammonium sulphate to obtain the protein precipitate, which was then dissolved in $20 \mathrm{mM}$ tris buffer for further evaluation.

\section{Determination of protein content}

The total protein content of the solutions at different stages of protein purification was determined by Bradford methods ${ }^{8}$ using Sigma's Bradford reagent (B6916). In this assay, a series of BSA standard solutions $(0.1-1.2 \mathrm{mg} / \mathrm{ml})$ were used to prepare the standard curve. Bradford assay was performed by adding $1 \mathrm{~mL}$ of Bradford reagent to $20 \mu \mathrm{l}$ of each standard solutions or unknown solution, and homogenized by using vortex mixer. The samples were incubated in dark conditions for 10 minutes and the absorbance was read at $595 \mathrm{~nm}$.

\section{SDS PAGE}

We performed sodium dodecyl sulfate (SDS) polyacrylamide gel electrophoresis (PAGE) using 12\% resolving and 5\% stacking gels for separating proteins. We followed the Laemmli's method ${ }^{9}$ for gel electrophoresis. The samples were mixed with equal volume of gel loading buffer and heated at $95^{\circ} \mathrm{C}$ in dry heating bath for 2 mins. The electrophoresis process was run with $90 \mathrm{~V}$ for first 10 mins and then run at $150 \mathrm{~V}$ with Biorad mini protean gel electrophoresis system. After complete run the gel was stained with Coomassie Brilliant Blue. We have used protein marker $(10 \mathrm{kD}$ to $250 \mathrm{kD})$ from $\mathrm{GCC}$ biotech (Pre-stained protein marker GCR-P4B) for determination of molecular weight. We imaged the gels in Biorad gel documentation system. Acrylamide, bis acrylamide, Tris and TEMED (T9281) are from Sigma Aldrich. Coomassie Brilliant Blue R250 (93473) and Ammonium per sulphate (28575) was from SRL (Sisco Research Laboratories).

\section{Purification of protein}

Dialysis: The pellet dissolved in Tris buffer as obtained above was then dialyzed in $3.5 \mathrm{~cm} / \mathrm{ml}$ dialysis tubing (SIGMA Aldrich D6066 overnight in a magnetic stirrer by immersing the tubing in a buffer containing Tris $(\mathrm{pH} 8)$ and phenylmethylsulfonyl fluoride (PMSF) SRL, which was repeated thrice for complete exchange of buffer.

Diethylaminoethyl (DEAE) cellulose ion exchange chromatography: The protein sample was loaded in the DEAE cellulose (SIGMA Aldrich 30477) column. Ion exchange column chromatography was carried out by using an assembly of Biorad's Econo pump model EP-1, UV monitor and chart recorder from Atto, Japan and Biorad's fraction collector model 2110. A gradient of $0.05 \mathrm{M}$ to $0.5 \mathrm{M} \mathrm{NaCl}$ was used to elute the protein from the column. The gradient was run for $150 \mathrm{~min}$ with a flow rate of $1 \mathrm{ml} / \mathrm{min}$. Optical density (OD) of all the fractions were taken at $280 \mathrm{~nm}$ with Schimadzu $2401 \mathrm{UV}$ Vis Spectrophotometer.

\section{Bovine serum albumin (BSA) digestion}

Samples at different stages of purification were tested for albuminolytic property of protease by using BSA SIGMA as substrate. BSA digestion was performed at $37^{\circ} \mathrm{C}$ and $\mathrm{pH} 7.5$ for 1 hour. Further, each of the samples were mixed with protein gel loading dye in 1:1 ratio and loaded in SDS PAGE and the gel was imaged with Biorad gel documentation system.

\section{Protease activity assay}

In this assay, $\beta$-casein was used as substrate. If protease digests casein, the amino acid tyrosine is liberated along with other peptide fragments. Folin's reagent reacts with free tyrosine to generate a blue colored product, which is quantifiable and measured as an absorbance value on the Schimadzu UV 2401 spectrophotometer at $660 \mathrm{~nm}$. A tyrosine standard calibration curve is constructed to determine the amount of tyrosine released after the proteolytic activity. A series of tyrosine standard solutions at different concentrations $(5-50 \mu \mathrm{g} / \mathrm{mL})$ were prepared from the $0.18 \mathrm{mg} / \mathrm{mL}$ L-tyrosine stock solution with deionized water. L-tyrosine was purchased from Himedia, Fohlin's reagent was obtained from SRL and $\beta$-casein from SIGMA.

\section{Effect of $\mathrm{pH}$ \& temperature on the protease activity}

We have assayed the protease activity in terms of caseinolytic activity with plant leaf extracts at different stages of purification (crude soup is the initial supernatant after homogenization and centrifugation, $40 \%$ ammonium soup is the phosphate dissolved pellet after $40 \%$ ammonium sulphate fractionation and pooled soup is the final collection of pure fractions came from DEAE cellulose column). All the three samples were dialysed to remove protease inhibitor and EDTA before the protease assay. The protease activity of pure protein was examined at different $\mathrm{pH}$ range $4-9$ and temperature range $4-70^{\circ} \mathrm{C}$.

\section{Enzyme kinetics assay at different $\beta$-casein concentration}

The enzyme activity assay for protease was conducted with different concentrations of $\beta$-casein as substrate, at $\mathrm{pH}-8$ in $37^{\circ} \mathrm{C}$ respective optimum conditions as determined with the previous experiments described above (optimum temperature and $\mathrm{pH}$ 
conditions). Here the substrate concentration ( $\beta$-casein) varied in the range $(0.81,1.6,2.4,4.03,5.2) \mathrm{mg} / \mathrm{ml}$ keeping the enzyme concentration fixed.

\section{Results}

Moringa oleifera leaves are reported to contain protease but there are no detailed studies on the purification and kinetic parameters of the enzyme. Here, we obtain partially purified protease from the aqueous extract of the leaves by ion exchange chromatography such that in anion exchange the proteins show a peak at $280 \mathrm{~nm}$ implying a positively charged protein.

\section{Purification of protease}

The protein concentration from mature Moringa oleifera leaves at various stages of purification is shown in Table 1, which was purified by DEAE cellulose ion exchange column chromatography. The chromatogram for purification is shown in Figure 1A. The purified fractions were observed in $12 \%$ SDS PAGE (Figure 1B). The protein was of $51 \mathrm{kDa}$ according to molecular weight markers.

\section{Table 1. Total protein content in different stages of purification.}

\begin{tabular}{|c|c|}
\hline Samples & $\begin{array}{c}\text { Protein } \\
\text { concentration(mg/ml) }\end{array}$ \\
\hline Crude & 0.56 \\
\hline $40 \%$ & 0.55 \\
\hline Pooled & 0.22 \\
\hline
\end{tabular}

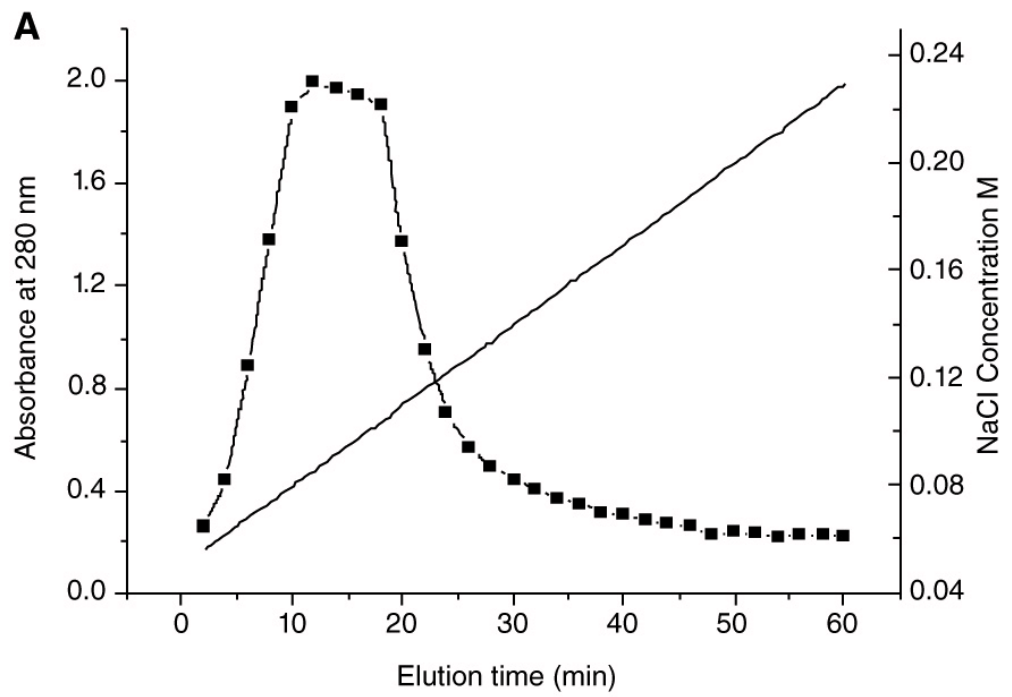

B

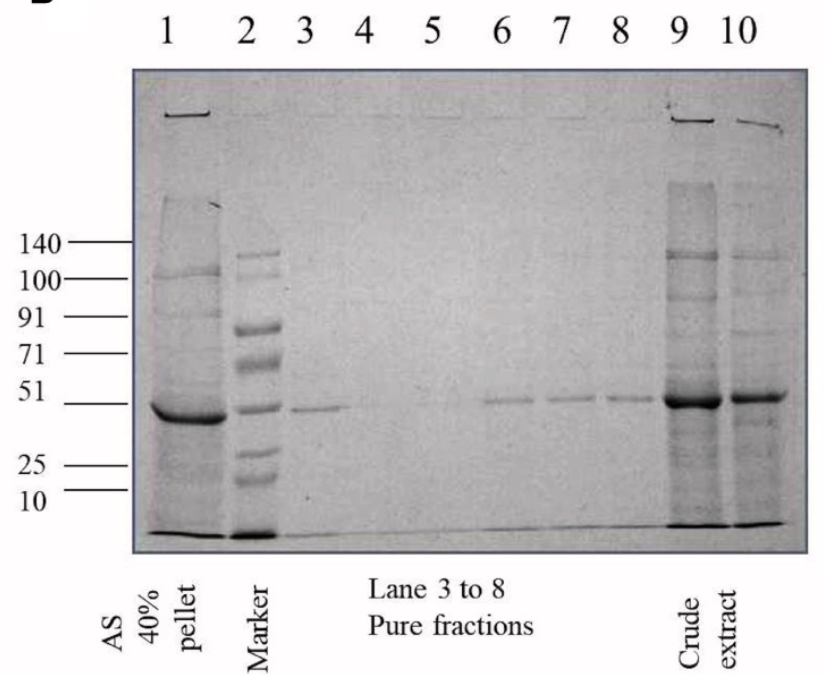

Figure 1. A. Chromatogram for the purification of protein from Moringa oleifera shows the elution time versus absorbance at $280 \mathrm{~nm}$ and the corresponding $\mathrm{NaCl}$ gradient profile (ranging from $0.04 \mathrm{M}$ to $0.25 \mathrm{M}$ ) for maximal elution $\mathbf{B}$. SDS PAGE of the crude extract and fractions after purification by DEAE cellulose ion exchange chromatography. Lane 1 shows extract after $40 \%$ ammonium sulphate precipitation, lane 2 shows the prestained molecular weight marker from GCC biotech marking 140, 100, 91, 71, 51, 25 and 10 kDa bands, lanes 3 to 8 represent fractions after column purification, lanes 9 and10 show the bands from crude leaf extract. 
BSA digestion and SDS PAGE

Results from Figure 2 shows that both crude extract and $40 \%$ ammonium sulfate fractionated sample possesses protease activity and is able to produce fragments of BSA (lane 5, 6 and 9).

Biophysical characterization of the protease

UV-vis absorption spectra of the pure protease were shown in Figure 3. A single peak at $280 \mathrm{~nm}$ can be observed for the pure protein.

Effect of $\mathrm{pH}$ on protease activity with $\beta$-casein as substrate In both crude extract and purified protein, protease activity was measured as described in methods. Reactions in different $\mathrm{pH}$ 4, 5, 6, 7, 8 and 9 were done (Figure 4). The results showed maximum activity at the $\mathrm{pH}$ 8.0. Therefore, the enzyme is an alkaline protease.
Effect of temperature on protease activity with $\beta$-casein as substrate.

The protease assay with $\beta$-casein as substrate was performed at a range of temperatures; $4^{\circ} \mathrm{C}, 25^{\circ} \mathrm{C} 37^{\circ} \mathrm{C}, 55^{\circ} \mathrm{C}$ and $70^{\circ} \mathrm{C}$ (Figure 5) according to the methods described above. The enzyme activity was found to be maximum at $37^{\circ} \mathrm{C}$.

\section{Enzyme kinetics}

Specific activity of the protease was calculated by enzyme activity from the protease assay using $\beta$-casein as substrate and the total protein content of the protease solution. We can see a large increase in specific activity after the final purification (Figure 6).

We have seen increasing protease activity in the initial substrate concentration range and then saturation of protease activity above concentration of $4.03 \mathrm{mg} / \mathrm{ml} \beta$-casein (Figure 7). The

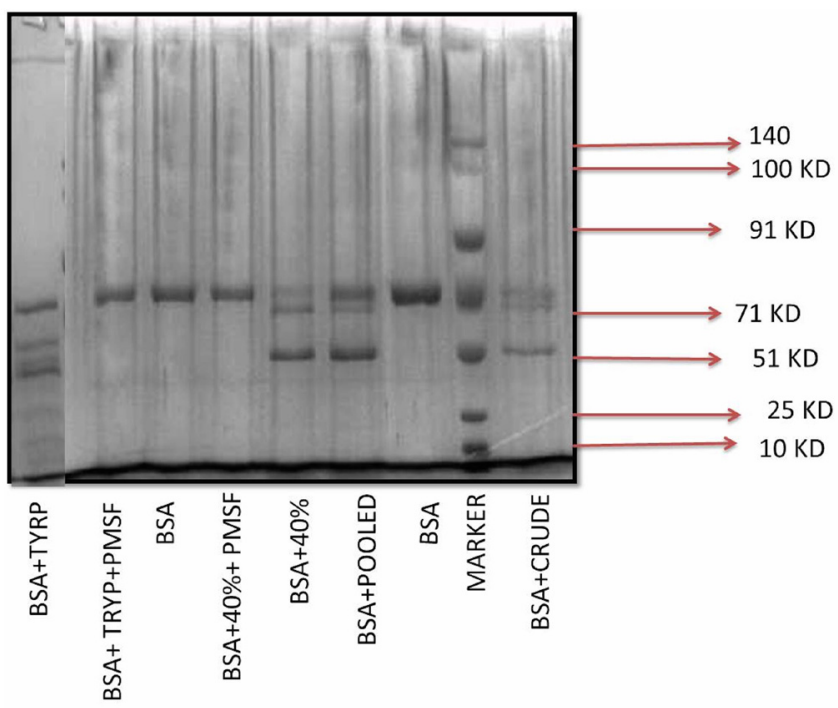

Figure 2. SDS PAGE showing BSA fragmentation by Moringa oleifera crude enzyme with trypsin as positive control. Lane 1 is BSA and trypsin, lane 2 is BSA + trypsin + PMSF, lane 3 is BSA, lane 4 is BSA +40\% Ammonium Sulphate cut + PMSF, lane 5 is BSA + 40\% Ammonium Sulphate cut, lane 6 is BSA + Pooled pure protein, lane 7 is BSA, lane 8 is prestained molecular weight marker from GCC biotech showing $140,100,91,71,51,25$ and $10 \mathrm{kDa}$ bands and lane 9 is BSA + crude leaf extract.

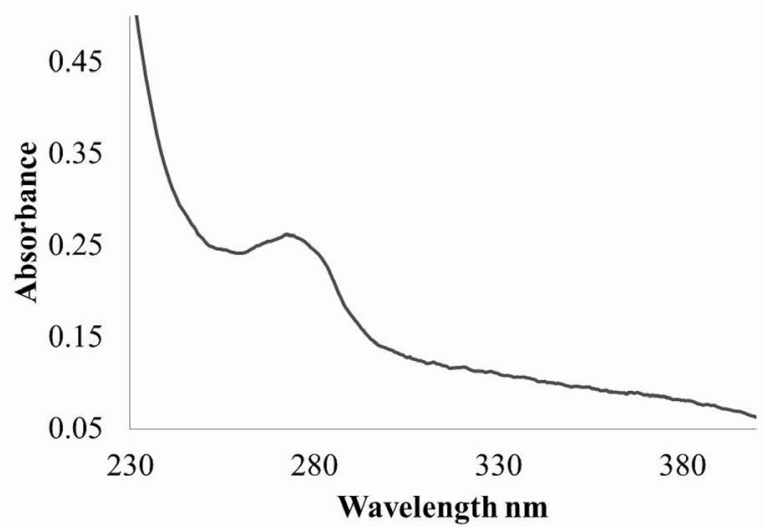

Figure 3. UV-Vis absorbance spectra from $(230 \mathrm{~nm}$ to $400 \mathrm{~nm})$ of the purified protein from Moringa oleifera leaf extract is shown. 


\section{AMOUNT OF TYROSINE LIBERATED IN DIFFERENT $\mathrm{PH}$}

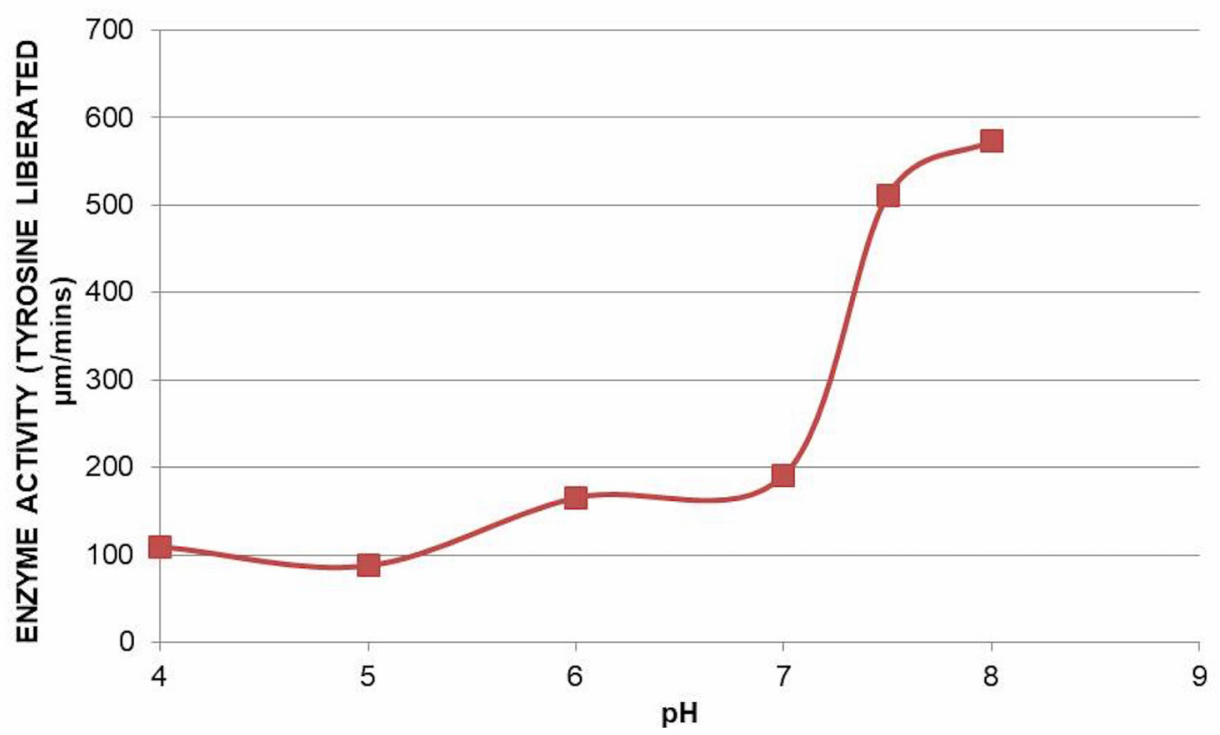

Figure 4. Effect of $\mathrm{pH}$ on the caseinolytic property of the protease. Protease activity of the pooled pure fractions on $\beta$-casein degradation is plotted against different $\mathrm{pH}(4,5,6,7$ and 8$)$ at $37^{\circ} \mathrm{C}$. Free tyrosine liberated due to $\beta$-casein degradation was monitored with Folin-Ciocalteau reagent at $660 \mathrm{~nm}$ and the corresponding amount was measured from the tyrosine standard curve.

\section{CASEINOLYTIC ACTIVITY AT DIFFERENT TEMPERATURE}

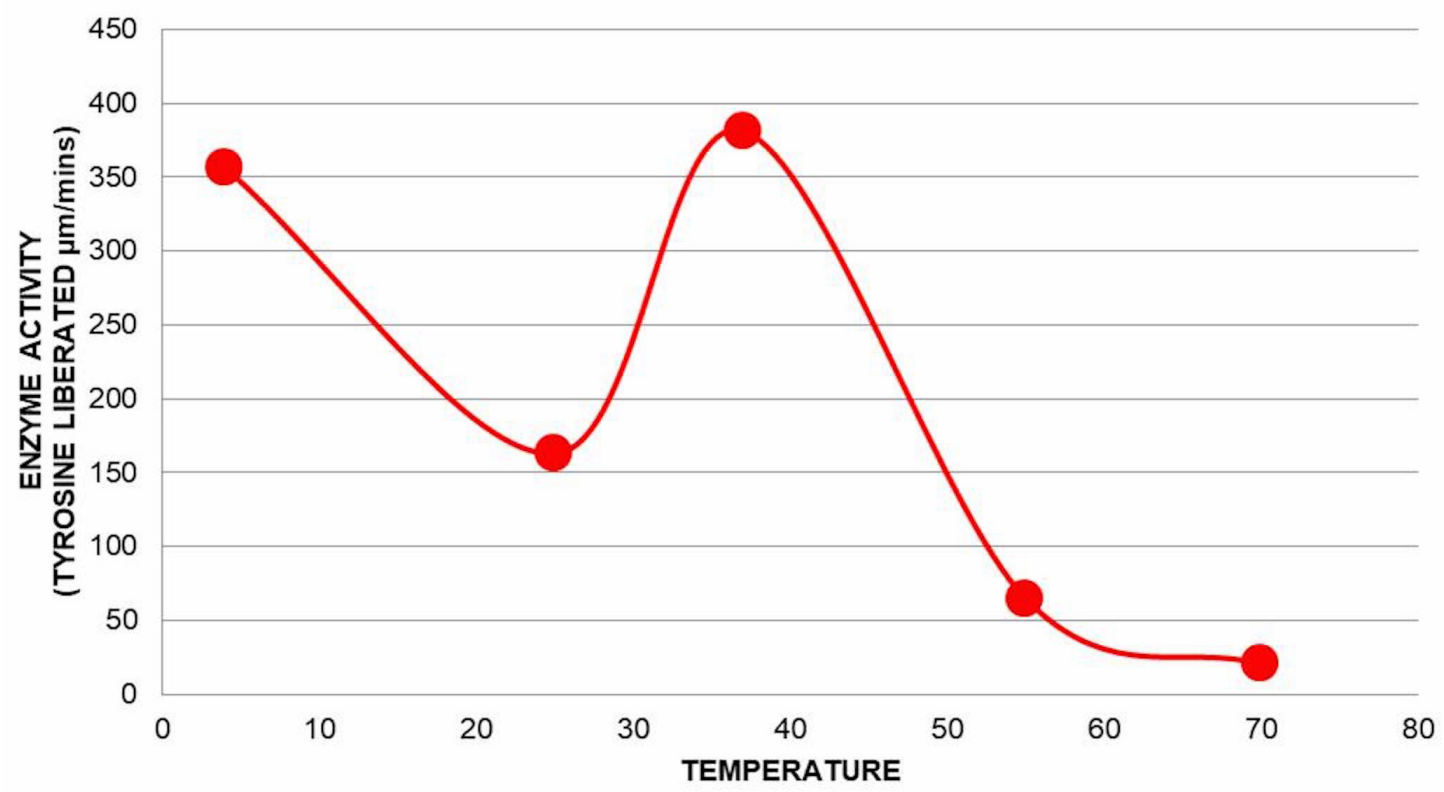

Figure 5. Effect of temperature on the caseinolytic property of the protease. Protease activity of the pooled pure fractions on $\beta$-casein degradation is plotted against different temperature $\left(4,25,37,55\right.$ and $\left.70^{\circ} \mathrm{C}\right)$ at $\mathrm{pH} 8$. Free tyrosine liberated due to $\beta$-casein degradation was measured as described earlier. 


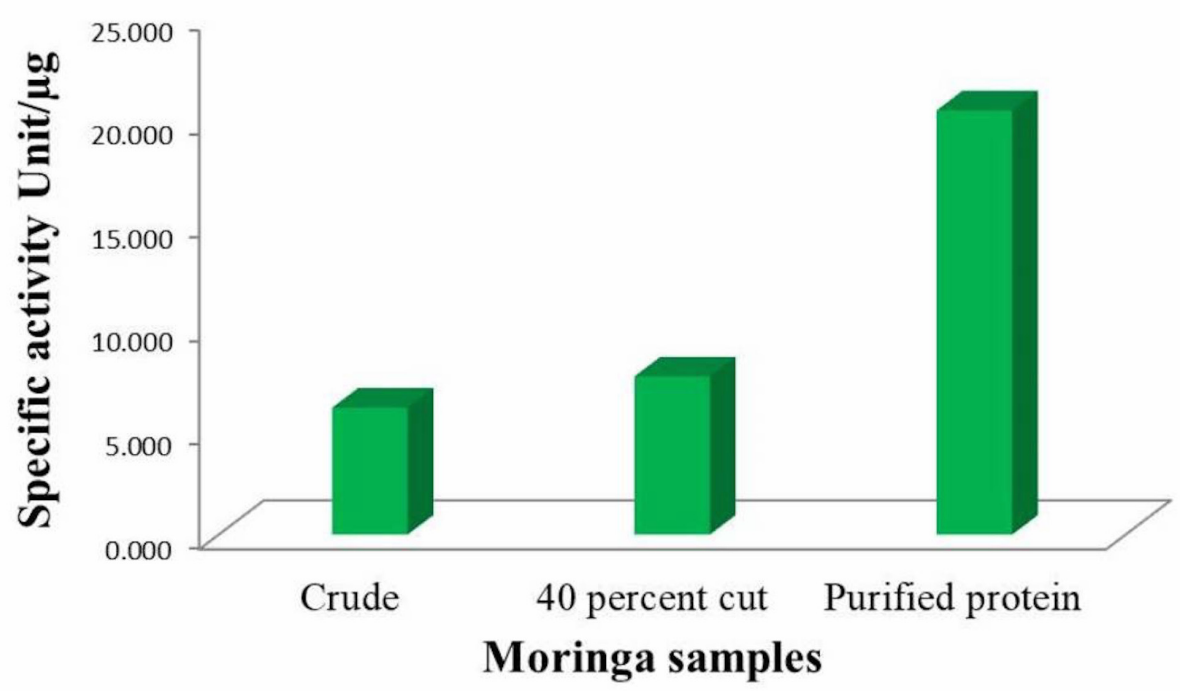

Figure 6. Comparison of specific activity of crude extract, $40 \%$ ammonium sulfate fraction and purified protease at optimum pH 8 and optimum temperature $37^{\circ} \mathrm{C}$ is represented as a bar diagram. Free tyrosine liberated due to $\beta$-casein degradation was measured as described earlier. Enzyme activity present per amount of enzyme is calculated as specific activity of the protease.

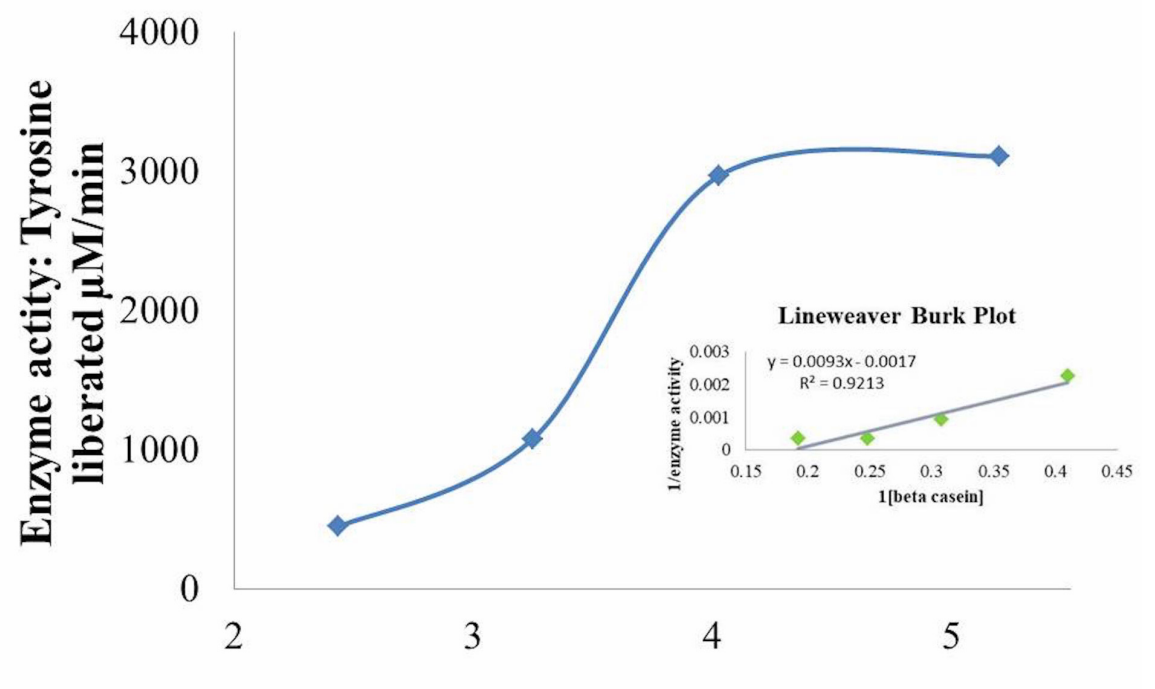

\section{Concentration of beta casein $\mathrm{mg} / \mathrm{ml}$}

Figure 7. Protease activity with different $\beta$ - casein concentrations is plotted to get Michaelis Menten curve and the double reciprocal plot (1/substrate concentration versus $1 /$ enzyme activity) is shown on the inset. $K_{M}$ and $V_{\max }$ obtained from the double reciprocal plot are $5.47 \mathrm{mg} / \mathrm{ml}$ and $588.23 \mu \mathrm{M} / \mathrm{min}$ respectively.

graph as a result follows conventional Michaelis Menten kinetics. We calculated $\mathrm{K}_{\mathrm{M}}$ and $\mathrm{V}_{\max }$ from the corresponding double reciprocal plot i.e. Lineweaver Burk plot as shown in the inset graph (Table 2). $\mathrm{K}_{\mathrm{M}}$ is $5.47 \mathrm{mg} / \mathrm{ml}$ and $\mathrm{V}_{\max }$ is $588.23 \mu \mathrm{M} / \mathrm{min}$.

\section{Dataset 1. Enzyme kinetics data}

http://dx.doi.org/10.5256/f1000research.15642.d212249

Zip file containing underlying data of all enzyme activity assays with raw gel images
Table 2. $K_{M}$ and Vmax from enzyme kinetics.

\begin{tabular}{|c|c|}
\hline $\mathbf{K}_{\mathbf{M}} \mathbf{m g} / \mathbf{m l}$ & $\mathbf{V m a x} \boldsymbol{\mu M} / \mathbf{m i n}$ \\
\hline 5.47 & 588.235 \\
\hline
\end{tabular}

\section{Discussion}

Our study concludes that mature leaves from Moringa oleifera contains a protease with an approximate molecular weight of 
$51 \mathrm{kD}$, with an optimum temperature of $37^{\circ} \mathrm{C}$ and optimum $\mathrm{pH}$ of 8.0 for its caseinolytic property. This is the first report of purification of a protease from Moringa oleifera to our knowledge. Further determination of molecular characterization, substrate specificity and activity of the protease are required to determine its suitability for industrial applications.

\section{Data availability}

Dataset 1: Enzyme kinetics data. Zip file containing underlying data of all enzyme activity assays with raw gel images 10.5256/ f1000research.15642.d212249
Competing interests

No competing interests were disclosed.

Grant information

The author(s) declared that no grants were involved in supporting this work.

\section{Acknowledgements}

We would like to acknowledge Mr Dipak Chandra Konar of Department of Chemistry, Bose Institute, for his help in using the protein purification set up, and spectrophotometric assays. Special thanks go to Prof. K. P Das, Bose Institute, for his support in this project.

\section{References}

1. López-Otín C, Overall CM: Protease degradomics: a new challenge for proteomics. Nat Rev Mol Cell Biol. 2002; 3(7): 509-519. PubMed Abstract | Publisher Full Text

2. Turk B: Targeting proteases: successes, failures and future prospects. Nat Rev Drug Discov. 2006; 5(9): 785-799. PubMed Abstract | Publisher Full Text

3. Li Q, Yi L, Marek $P$, et al:: Commercial proteases: present and future. FEBS Lett. 2013; 587(8): 1155-1163.

PubMed Abstract | Publisher Full Text

4. López-Otín C, Bond JS: Proteases: multifunctional enzymes in life and disease. J Biol Chem. 2008; 283(45): 30433-30437. PubMed Abstract | Publisher Full Text | Free Full Text

5. Li S, Yang X, Yang S, et al.: Technology prospecting on enzymes: application, marketing and engineering. Comput Struct Biotechnol J. 2012; 2(3):

e201209017.

PubMed Abstract | Publisher Full Text | Free Full Text
6. Stohs SJ, Hartman MJ: Review of the Safety and Efficacy of Moringa oleifera. Phytother Res. 2015; 29(6): 796-804. PubMed Abstract | Publisher Full Text

7. Satish A, Sairam S, Ahmed F, et al.: Moringa oleifera Lam.: Protease activity against blood coagulation cascade. Pharmacognosy Res. 2012; 4(1): 44-49. PubMed Abstract | Publisher Full Text | Free Full Text

8. Bradford MM: A rapid and sensitive method for the quantitation of microgram quantities of protein utilizing the principle of protein-dye binding. Anal Biochem. 1976; 72(1-2): 248-254. PubMed Abstract | Publisher Full Text

9. Laemmli UK: Cleavage of structural proteins during the assembly of the head of bacteriophage T4. Nature. 1970; 227(5259): 680-5.

PubMed Abstract | Publisher Full Text

10. Banik S, Biswas S, Karmakar S: Dataset 1 in: Extraction, purification, and activity of protease from the leaves of Moringa oleifera. F1000Research. 2018 http://www.doi.org/10.5256/f1000research.15642.d212249 


\section{Open Peer Review}

\section{Current Peer Review Status:}

\section{Version 1}

Reviewer Report 25 September 2018

https://doi.org/10.5256/f1000research.17067.r36602

(C) 2018 Nath S. This is an open access peer review report distributed under the terms of the Creative Commons Attribution License, which permits unrestricted use, distribution, and reproduction in any medium, provided the original work is properly cited.

\section{Somsubhra Nath}

Basic Research and Molecular Biology division, Saroj Gupta Cancer Centre and Research Institute, West Bengal, India

The manuscript by Banik et al. describes the isolation and further characterization of protease activity of partially purified protein fraction from the leaves of Moringa oleifera. The manuscript is well-written with detailed description of materials, methods and results. It, indeed, identified the protease activity with sufficient detailing. It has the potential for future investigation of biochemical characterization and functional relevance of this plant derived protease.

However, there are a few concerns, as pointed below:

1. In Figure 2, it is apparent that the first lane is not a part of original figure. Adding a separate lane in an otherwise complete picture is not accepted. A repeat experiment with all the lanes is suggested.

2. The referencing requires to be more elaborate.

3. The discussion should describe potential application of the findings, based on literature review.

Addressing these issues will strengthen the acceptability of the finding described in this manuscript.

Is the work clearly and accurately presented and does it cite the current literature? Yes

Is the study design appropriate and is the work technically sound? Yes

Are sufficient details of methods and analysis provided to allow replication by others? Yes 


\section{If applicable, is the statistical analysis and its interpretation appropriate? Not applicable}

\section{Are all the source data underlying the results available to ensure full reproducibility? No source data required}

\section{Are the conclusions drawn adequately supported by the results? Yes}

Competing Interests: No competing interests were disclosed.

I confirm that I have read this submission and believe that I have an appropriate level of expertise to confirm that it is of an acceptable scientific standard.

Reviewer Report 18 September 2018

https://doi.org/10.5256/f1000research.17067.r38435

C 2018 Roy S. This is an open access peer review report distributed under the terms of the Creative Commons Attribution License, which permits unrestricted use, distribution, and reproduction in any medium, provided the original work is properly cited.

\section{Sujit Roy}

Department of Botany, UGC Centre of Advanced Studies, The University of Burdwan, Burdwan, West Bengal, India

The article entitled 'Extraction, purification, and activity of protease from the leaves of Moringa oleifera' by Banik et al. appears to be an interesting topic related to purification of protease from an economically and medicinally important plant species Moringa oleifera.

Overall, the manuscript is well composed, the background and objectives of the study has been mentioned clearly and also justified. The introduction part also appropriately reviews some of the relevant information. The results are sound and explained properly and supported with further explanation in the Discussion part. Therefore, in summary, I'm recommending acceptance and publication of this article.

However, for future research interest, the introduction section could have been more extensive, indicating relevant information from recent past and current studies for getting meaningful insight into the background of this research as well as the lacunae which motivated to set the objectives for carrying out this study.

The methods part is quite sufficient. However, for the purification part, describing the isolation of the indicated protease activity from Moringa leaf extracts may be more extensive and apart from Coomassie blue staining, quality of purification may be assessed by silver staining procedure to compare the results and enrichment of purification after the column chromatographic techniques. 
Finally, a discussion section may be included to compare and discuss the findings in light of the related research. In concluding note, application and future research possibilities using the gained knowledge and information may be mentioned.

Is the work clearly and accurately presented and does it cite the current literature? Yes

Is the study design appropriate and is the work technically sound?

Yes

Are sufficient details of methods and analysis provided to allow replication by others? Yes

If applicable, is the statistical analysis and its interpretation appropriate? Yes

Are all the source data underlying the results available to ensure full reproducibility? Yes

Are the conclusions drawn adequately supported by the results? Yes

Competing Interests: No competing interests were disclosed.

Reviewer Expertise: DNA damage repair mechanism in plants under abiotic stress

I confirm that I have read this submission and believe that I have an appropriate level of expertise to confirm that it is of an acceptable scientific standard.

Reviewer Report 18 September 2018

https://doi.org/10.5256/f1000research.17067.r38180

(C) 2018 Banerjee $\mathbf{R}$ et al. This is an open access peer review report distributed under the terms of the Creative Commons Attribution License, which permits unrestricted use, distribution, and reproduction in any medium, provided the original work is properly cited.

\section{Rajat Banerjee}

Department of Biotechnology, Dr. B. C. Guha Centre for Genetic Engineering and Biotechnology, University of Calcutta, Kolkata, West Bengal, India

Priyanka Biswas

Department of Biotechnology, Centre for Genetic Engineering and Biotechnology, University of Calcutta, Kolkata, West Bengal, India

The research article entitled "Extraction, purification, and activity of protease from the leaves of Moringa oleifera by Banik S, Biswas S and Karmakar S" explains the extraction, purification and 
activity of a protease that has been isolated from the leaves of the plant Moringa oleifera. The work is unique and can be of great applications since Moringa oleifera is reported to have various medicinal properties.

This work may be recommended for indexing only after incorporation of a few changes listed as follows:

\section{Major Revision:}

1. Figure 2 - Lane numbers are missing; Marker positioning wrong; data of $B S A+P O O L E D+P M S F$ and BSA+CRUDE+PMSF missing. Try to include these data for a better clarification to the readers.

2. Figure 4 - What happens after $\mathrm{pH} 8$, is not reflected in the graph? Then how can this be concluded as optimum $\mathrm{pH}$ ? A range of $\mathrm{pH} 4-12$ at least, would be better for any such conclusion.

3. Figure 5 - The data points are very scattered. More data points must be included in the graph for proper conclusion, especially between $25^{\circ} \mathrm{C}$ and $37^{\circ} \mathrm{C}$ and $37^{\circ} \mathrm{C}$ and $55^{\circ} \mathrm{C}$.

4. Figure 7 - This is very confusing. The graph does not look like a Michaelis - Menten graph. Number of data points must be increased. $\mathrm{K}_{\mathrm{m}}$ is outside the substrate concentration range taken in the graph. $\mathrm{K}_{\mathrm{m}}$ is usually expressed in units of $\mu \mathrm{M}$ or $\mathrm{mM}$ and not $\mathrm{mg} / \mathrm{ml}$. The Lineweaver-Burk plot is also erroneous. If the linear line is extrapolated backwards, it will give a negative $y$-intercept, i.e., a negative $1 / \mathrm{V}_{\max }$ value. The $\mathrm{V}_{\max }$ values obtained by the authors can neither be correlated to the Michaelis - Menten graph nor to the LineweaverBurk plot. Then how is this value obtained?

\section{Minor Revision:}

1. Under the Methods section, in Preparation of crude extract and Purification of protein, the authors have used "Tris" buffer. It is usually written as Tris-HCl buffer. Moreover, under the two above mentioned sub-headings, somewhere the $\mathrm{pH}$ of the buffer is missing and elsewhere its concentration. Clear information should be provided.

2. Under the Enzyme kinetics assay, it is written "keeping the enzyme concentration fixed". The concentration used must be specified.

3. Figure $1 \mathrm{~B}$ - is a bit confusing. Marker should be preferably loaded into any of the side lanes. AS $40 \%$ pellet also has multiple bands, quite similar to the ladder. If possible, change the gel picture with proper loading arrangement and labelling.

4. Figure 3 - The peak at $280 \mathrm{~nm}$ is quite blunt and the $260 / 280$ ratio is close to 1 , suggesting the presence of impurities. Purer fractions must be used.

5. Figure 6 - There is no need to write "Moringa samples" in the X-axis title. Instead, it should be mentioned in the figure legend as "Samples from Moringa oleifera".

6. Why is this paper cited as a reference as well? Can this be done? Details about the datasheet is provided in the manuscript itself, after conclusion.

Is the work clearly and accurately presented and does it cite the current literature? Partly

Is the study design appropriate and is the work technically sound?

Yes

Are sufficient details of methods and analysis provided to allow replication by others? Yes 
If applicable, is the statistical analysis and its interpretation appropriate?

Not applicable

Are all the source data underlying the results available to ensure full reproducibility? Yes

Are the conclusions drawn adequately supported by the results?

Yes

Competing Interests: No competing interests were disclosed.

We confirm that we have read this submission and believe that we have an appropriate level of expertise to confirm that it is of an acceptable scientific standard, however we have significant reservations, as outlined above.

The benefits of publishing with F1000Research:

- Your article is published within days, with no editorial bias

- You can publish traditional articles, null/negative results, case reports, data notes and more

- The peer review process is transparent and collaborative

- Your article is indexed in PubMed after passing peer review

- Dedicated customer support at every stage

For pre-submission enquiries, contact research@f1000.com 